\title{
TINDAK PIDANA PENGGELAPAN DANA KOPERASI OLEH PENGURUS DI TINJAU DARI UNDANG-UNDANG NOMOR 25 TAHUN 1992 TENTANG PERKOPERASIAN
}

\author{
Dhevi Nayasari Sastradinata, SH, MM
}

\begin{abstract}
Abstrak
Hampir diseluruh dunia orang mengenal koperasi. Walaupun per definisi Koperasi dipahami dengan cara berbeda-beda, tetapi secara umum Koperasi dikenal sebagai suatu perusahaan yang unik, Koperasi adalah badan hukum yang berdasarkan atas asa kekeluargaan yang anggotanya terdiri dari orang perorangan atau badan hukum dengan tujuan untuk mensejahterakan anggotanya Umumnya koperasi dikendalikan secara bersama oleh seluruh anggotanya, dimana setiap anggota memiliki hak suara yang sama dalam setiap keputusan yang diambil koperasi.
\end{abstract}

\section{Kata Kunci : Koperasi Indonesia}

\section{PENDAHULUAN}

Hampir diseluruh dunia orang mengenal koperasi. Walaupun per definisi Koperasi dipahami dengan cara berbedabeda, tetapi secara umum Koperasi dikenal sebagai suatu perusahaan yang unik. Ia tidak hanya dianggap berbeda dari perusahaan peseorangan yang ber bentuk $\mathrm{CV}$, tapi juga dianggap tidak sama dengan perusahaan-perusahaan yang dimiliki oleh sekumpulan orang seperti Firma dan Perseorangan Terbatas (PT) . ${ }^{40}$

Secara Umum Koperasi dipahami sebagai perkumpulan orang yang secara sukarela mempersatukan diri untuk memperjuangkan peningkatan kesejahteraan ekonomi mereka,melalui pembentukan sebuah perusahaan yang dikelola secara demokratis. ${ }^{41}$ Praktek koperasi simpan pinjam hampir sama dengan Bank tetapi dengan tetap memegang prinsip perkoperasian yaitu kekeluargaan dan gotong royong. Asas kekeluargaan sebenarnya menunjukkan individu yang bergabung dalam kelompok. Individu meminjam uang dari koperasi berarti meminjam uang kelompok. Individu yang bergabung dalam koperasi akan melakukan interaksi dengan anggota koperasi lain. Individu saling berinteraksi sehingga muncullah kelompok. Kelompok yang solid dengan

\footnotetext{
${ }^{40}$ Revrisond Baswir.Koperasi Indonesia.BPFE-YOGYAKARTA.h.1. ${ }^{41}$ Ibid.
}

tujuan, norma, prilaku tertentu akan mendukung pencapaian tujuan koperasi. Sebaliknya kelompok yang tidak solid dengan adanya individu yang tidak mendukung tercapainya tujuan kelompok yang tercantum dalam aturan koperasi. Dan individu yang berprilaku tidak sesuai dengan tujuan koperasi akan di pecat menurut Buttutasik (dalam PIP, 2005). Dengan demikian kelompok yang kohesiv tetap dapat mencapai tujuan kinerja yang baik (makalah pendidikanunmura.blogspot.com/2013). ${ }^{42}$ Salah satu aspek terjadinya kohesivitas adalah lamanya interaksi antara anggota koperasi. Periode waktu kelompok di koperasi akan membawa tahap kohesivitas kelompok. Kohesivitas yang produktif akan dipengaruhi olleh lamanya interaksi antar individu baik karena lamanya tetapi juga intensitas interaksi antar individu. Di Indonesia pengenalan koperasi memang dilakukan oleh dorongan pemerintah, bahkan sejak pemerintahan penjajahan Belanda telah mulai diperkenalkan. Gerakan koperasi sendiri mendeklarasikan sebagai suatu gerakan sudah dimulai sejak tanggal 12 Juli 1947 melalui Kongres Koperasi di Tasikmalaya. Pengalaman di tanah air kita lebih unik karena koperasi yang pernah lahir dan telah tumbuh secara

http://makalahpendidikanunmura.blogspot.com/201 3/03/makalah-ukm-koperasi.html 
alami di jaman penjajahan, kemudian setelah kemerdekaan diperbaharui dan diberikan kedudukan yang sangat tinggi dalam penjelasan undang-undang dasar. Dan atas dasar itulah kemudian melahirkan berbagai penafsiran bagaimana harus mengembangkan koperasi.Paling tidak dengan dasar yang kuat tersebut sejarah perkembangan koperasi di Indonesia telah mencatat tiga pola pengembangan koperasi. ${ }^{43}$

Secara khusus pemerintah memerankan fungsi "regulatory" dan "development" secara sekaligus (Shankar 2002). Ciri utama perkembangan koperasi di Indonesia adalah dengan pola penitipan kepada program yaitu: ${ }^{44}$

1. Program pembangunan secara sektoral seperti koperasi pertanian, koperasi desa,KUD;

2. Lembaga-lembaga pemerintah dalam koperasi pegawai negeri dan koperasi fungsional lainnya; dan

3. Perusahaan baik milik negara maupun swasta dalam koperasi karyawan. Sebagai akibatnya prakarsa masyarakat luas kurang berkembang dan kalu ada tidak diberikan tempat semestinya.

Menurut James A.F Stoner pengertian organisasi adalah sebagai alat (tools) untuk mencapai tujuan. Pekerjaan untuk mengkoordinasikan sumber daya manusia dan sumber daya modal yang dimiliki oleh organisasi tersebut pengorganisasian (organizing), dan dilakukan oleh seorang manajer (Koperas, teori dan praktek Oleh Sitio, A.,dkk). Struktur organisasi dapat didefinisikan sebagai susunan dan hubungan antarkomponen dan antarposisi dalam suatu perusahaan. Struktur organisasi menunjukkan hirarki organisasi dan struktur wewenang, serta memperlihatkan aliran pelaporannya. Selain, itu struktur organisasi memberikan stabilitas dan kelanjutan hidup organisasi, walaupun sumber daya manusia di dalamnya silih berganti. Koperasi sebagai sebuah

$$
{ }^{43} \text { Ibid }
$$

organisasi mempunyai ciri-ciri yang unik, yang membedakannya dengan yang lain. Berikut ini akan dibahas beberapa pendapat mengenai pengertian koperasi. ${ }^{45}$

Koperasi dikenalkan di Indonesia oleh seorang Pamong Praja Patih R.Aria Wiria Atmaja di Purwokerto, Jawa Tengah pada tahun 1896. Pada tanggal 12 juli 1947, pergerakan koperasi di Indonesia mengadakan konggres koperasi yang pertama di Tasikmalaya. Tanggal dilaksanakannya konggres ini kemudian ditetapkan sebagai Hari Koperasi Indonesia. ${ }^{46}$ Koperasi adalah badan hukum yang berdasarkan atas asa kekeluargaan yang anggotanya terdiri dari orang perorangan atau badan hukum dengan tujuan untuk mensejahterakan anggotanya. Umumnya koperasi dikendalikan secara bersama oleh seluruh anggotanya, dimana setiap anggota memiliki hak suara yang sama dalam setiap keputusan yang diambil koperasi. Pembagian keuntungan koperasi biasa disebut sisa hasil usaha (SHU) biasanya dihitung berdasarkan andil. ${ }^{47}$ Penulis juga menganalisis sejumlah potensi masalah yang bisa timbul dari penggelapan dana koperasi oleh pengurus kopersi. Seiring berkembangnya zaman dan sistem hukum, Undang-Undang nomor 25 tahun 1992 tentang koperasi ini penerapannya semoga dapat terus dikritisi oleh para ahli hukum, terutama untuk mengantisipasi potensi masalah.

\section{METODE PENELITIAN}

Tipe Penelitian hukum yang di lakukan adalah penelitian Yuridis normatife (hukum normatif). Metode Penelitian Hukum normatif adalah suatu prosedur penelitian ilmiah untuk menemukan

45

http://www.apapengertianahli.com/2015/01/pen gertian-koperasi-tujuan-fungsi-jeniskoperasi.html\#_

$$
46
$$

http://injadul.blogspot.com/2012/10/pengertians ejarahkonseplatar-belakang.html

${ }^{47}$ Revrisond Baswir.Koperasi Indonesia.BPFE-YOGYAKARTA.h.6. 
kebenaran berdasarkan logika keilmuan hukum dari sisi normatifnya. ${ }^{48}$ Bahanbahan tersebut disusun secara sistematis, dikaji kemudian dicari suatu kesimpulan dalam hubungannya dengan masalah yang diteliti.

\section{HASIL DAN PEMBAHASAN}

Berdasarkan kutipan penjelasan pasal 33 Undang-Udang Dasar 1945 dan pasal 1 Undang-Undang nomor.25 tahun1992 tersebut,dapat diketahui bahwa Koperasi di Indonesia tidak semata-mata dipandang sebagai bentuk perusahaan sebagaimana halnya Perseroan Terbatas. ${ }^{49}$ Koperasi sebagai sebuah organisasi mempunyai ciri-ciri yang unik, yang membedakannya dengan yang lain. Berikut ini akan dibahas beberapa pendapat mengenai pengertian koperasi. ${ }^{50}$ Koperasi mengandung makna kerja sama. Kooperasi (cooperative) bersumber dari kata Coopere (latin) co-operation yang berarti kerja sama. Ada juga yang mende finisikan koperasi dala makna lain. Menurut Enriques, pengertian koperasi adalah menolong satu sama lain (to help one another) atau saling bergandengan tangan (hand it hand).DI indonesia disebut kerja sama atau menurut Notoatmojo disebut gotong royong yang telah dikenal oleh Indonesia sejak tahun 2000 SM. Istilah gotong royong diberbagai daerah seperti tapanuli disebut Marsiurupan, di Minahasa disebut mapalus kobeng, di Sumba "Pawonda", di Ambon "Masohi", di Jawa barat "Liliuran" dan Madura "Long tinolong" dan di Sumatera Barat "Julojulo" dan di Bali "Subak". Pengurus koperasi dipilih dari kalangan dan oleh anggota dalam suatu rapat anggota. Ada kalanya rapat anggota tersebut tidak berhasil memilih seluruh anggota Pengurus dari kalangan anggota sendiri. Hal demikian umpamanya terjadi jika calon-calon yang berasal dari kalangankalangan anggota sendiri tidak memiliki

48 Jhonny ibrahim, Teori \& Metode Penelitian Hukum Normatif, Banyumedia Publishing, Malang 2006.h .57.

${ }^{49}$ Revrisond Baswir.Koperasi

Indonesia.BPFE-YOGYAKARTA.h.6.

${ }^{50}$ Revrisond Baswir. Koperasi

Indonesia.BPFE-YOGYAKARTA.h.1. kesanggupan yang diperlukan untuk memimpin koperasi yang bersangkutan, sedangkan ternyata bahwa yang dapat memenuhi syarat-syarat ialah mereka yang bukan anggota atau belum anggota koperasi (mungkin sudah turut dilayani oleh koperasi akan tetapi resminya belum meminta menjadi anggota). ${ }^{51}$

"Koperasi adalah badan
usaha yang beranggotakan
orang-seorang atau badan
hukum koperasi, dengan
melandaskan kegiataannya
berdasarkan prinsip
koperasi sekaligus sebagai
gerakan ekonomi rakyat
yang berdasar atas azas
kekeluargaan."

Dari beberapa pengertian diatas sehingga dapat kami simpulkan, bahwa Koperasi adalah suatu perkumpulan orang orang atau badan hukum yang tujuannya untuk kesejahteraan bersama dan didalam perkumpulan tersebut mengandung azas kekeluargaan yang saling bergotong royong dan tolong menolong diantara anggota.

Menurut Undang-undang Nomor 12 tahun 1967 tentang pokok-pokok perkoperasian, menyebutkan bahwa :

"Koperasi Indonesia adalah organisasi ekonomi rakyat berwatak sosial, beranggotakan orang-orang atau badan hukum koperasi yang merupakan tata susunan ekonomi sebagai usaha bersama berdasar atas asas kekeluargaan"(pasal 3 UU No.12/1967)".

Menurut Undang-Undang Nomor 25 Tahun 1992 Tentang Perkoperasian Pasal 1 Ayat 1 tentang perkoperasian menyatakan bahwa :

"koperasi adalah "badan usaha yang beranggotakan orang seorang atau badan hukum koperasi dengan melandaskan kegiatannya berdasarkan prinsip koperasi dan sekaligus sebagai

${ }^{51}$ http://id.wikipedia.org/wiki/Koperasi 
gerakan ekonomi rakyat yang berdasar atas asas kekeluargaan”.

Koperasi merupakan kumpulan orang dan bukan kumpulan modal. Koperasi harus betul-betul mengabdi kepada kepentingan perikemanusiaan semata-mata dan bukan kepada kebendaan. Kerjasama dalam koperasi didasarkan pada rasa persamaan derajat, dan kesadaran para anggotanya. Koperasi merupakan wadah demokrasi ekonomi dan sosial. Koperasi adalah milik bersama para anggota, pengurus maupun pengelola. Usaha tersebut diatur sesuai dengan keinginan para anggota melalui musyawarah rapat anggota. Koperasi sebagai badan usaha dapat melakukan kegiatan usahanya sendiri dan dapat juga kerja sama dengan badan usaha lain, seperti perusahaan swasta maupun perusahaan negara. Perbedaan antara koperasi dan badan usaha lain, dapat digolongkan sebagai berikut $:^{52}$

\section{a. Dilihat dari segi organisasi}

Koperasi adalah organisasi yang mempunyai kepentingan yang sama bagi para anggotanya. Dalam melaksanakan usahanya, kekuatan tertinggi pada koperasi terletak di tangan anggota, sedangkan dalam badan usaha bukan koperasi, anggotanya terbatas kepada orang yang memiliki modal, dan dalam melaksanakan kegiatannya kekuasaan tertinggi berada pada pemilik modal usaha.

Berdasarkan Pasal 5 Undangundang Nomor 25 Tahun 1992 Tentang Perkoperasiandisebutkan yakni :

“1) Koperasi melaksanakan prinsip koperasi sebagai berikut:

a.Keanggotaan bersifat
sukarela dan terbuka
b. Pengelolaan
dilakukan secara demokratis
c.Pembagian sisa hasil usaha
dilakukan secara adil
sebanding dengan besarnya

UURI.No.25th.1992.perkoperasian.mediacenter.h.7 jasa usaha masing-masing anggota

d. Pemberian balas jasa yang terbatas terhadap modal

\section{e.Kemandirian}

Penjelasan dari pasal tersebut juga didapatkan beberapa ciri dari koperasi ialah $:^{53}$

1) Sifat sukarela pada keanggotannya

2) Rapat anggota merupakan kekuasaan tertinggi dalam kopeerasi

3) Koperasi bersifat nonkapitalis

4) Kegiatannya berdasarkan pada prinsip swadaya (usaha sendiri), swakerta (buatan sendiri), swasembada (kemampuan sendiri).

5) Perkumpulan orang.

6) Pembagian keuntungan menurut perbandingan jasa. Jasa modal dibatasi.

7) Tujuannya meringankan beban ekonomi anggotanya, memperbaiki kesejahteraan anggotanya, pada khususnya dan masyarakat pada umumnya.

8) Modal tidak tetap, berubah menurut banyaknya simpanan anggota.

9) Tidak mementingkan pemasukan modal/pekerjaan usaha tetapi keanggotaan pribadi dengan prinsip kebersamaan.

10) Dalam rapat anggota tiap anggota masing-masing satu suara tanpa memperhatikan jumlah modal masing-masing.

11) Setiap anggota bebas untuk masuk/keluar (anggota berganti) sehingga dalam koperasi tidak terdapat modal permanen.

12) Seperti halnya perusahaan yang terbentuk Perseroan Terbatas (PT) maka Koperasi mempunyai bentuk Badan Hukum.

13) Menjalankan suatu usaha.

14) Penanggungjawab koperasi adalah pengurus.

15) Koperasi bukan kumpulan modal beberapa orang yang bertujuan mencari laba sebesar-besarnya.

16) Koperasi adalah usaha bersama kekeluargaan dan kegotong-

\section{${ }^{53}$ Ibid}


royongan. Setiap anggota berkewajiban bekerja sama untuk mencapai tujuan yaitu kesejahteraan para anggota.

17) Kerugian dipikul bersama antara anggota. Jika koperasi menderita kerugian, maka para anggota memikul bersama. Anggota yang tidak mampu dibebaskan atas beban/tanggungan kerugian. Kerugian dipikul oleh anggota yang mampu.

Di dalam Undang-undang Nomor 25 Tahun 1992 tentang perkoperasian pasal 15 menyatakan jenis koperasi yakni : "jenis koperasi didasarkan pada kesamaan kegiatan dan kepentingan ekonomi anggotanya"

Sedangkan Penjelasan mengenai Jenis Koperasi menurut fungsinya ${ }^{54}$

1) Koperasi

pembelian/pengadaan/konsumsi

adalah koperasi yang menyelenggarakan fungsi pembelian atau pengadaan barang dan jasa untuk memenuhi kebutuhan anggota sebagai konsumen akhir. Di sini anggota berperan sebagai pemilik dan pembeli atau konsumen bagi koperasinya.

2) Koperasi penjualan/pemasaran adalah koperasi yang menyelenggarakan fungsi distribusi barang atau jasa yang dihasilkan oleh anggotanya agar sampai di tangan konsumen. Di sini anggota berperan sebagai pemilik dan pemasok barang atau jasa kepada koperasinya.

3) Koperasi produksi adalah koperasi yang menghasilkan barang dan jasa, dimana anggotanya bekerja sebagai pegawai atau karyawan koperasi. Di sini anggota berperan sebagai pemilik dan pekerja koperasi.

4) Koperasi jasa adalah koperasi yang menyelenggarakan pelayanan jasa yang dibutuhkan oleh anggota, misalnya: simpan pinjam, asuransi, angkutan, dan sebagainya. Di sini anggota berperan sebagai pemilik dan pengguna layanan jasa koperasi.

Di dalam Undang-undang Nomor 25 Tahun 1992 tentang perkoperasian pasal 15 menyatakan bentuk koperasi yakni :

"Koperasi dapat berbentuk koperasi primer atau sekunder"

Apabila

koperasi menyelenggarakan satu fungsi disebut koperasi tunggal usaha (single purpose cooperative), sedangkan koperasi yang menyelenggarakan lebih dari satu fungsi disebut koperasi serba usaha (multi purpose cooperative).

Jenis koperasi berdasarkan tingkat dan luas daerah kerja: ${ }^{55}$

\section{1) Koperasi Primer}

Koperasi primer ialah koperasi yang yang minimal memiliki anggota sebanyak 20 orang perseorangan.

2) Koperasi Sekunder

Adalah koperasi yang terdiri dari gabungan badan-badan koperasi serta memiliki cakupan daerah kerja yang luas dibandingkan dengan koperasi primer. Koperasi sekunder dapat dibagi menjadi :

3) koperasi pusat

adalah koperasi yang beranggotakan paling sedikit 5 koperasi primer

\section{4) gabungan koperasi}

adalah koperasi yang anggotanya minimal 3 koperasi pusat

5) induk koperasi - adalah koperasi yang minimum anggotanya adalah 3 gabungan koperasi

Jenis Koperasi menurut status keanggotaannya :56

\section{1) Koperasi produsen}

adalah koperasi yang anggotanya para produsen barang/jasa dan memiliki rumah tangga usaha.

\section{2) Koperasi konsumen}

adalah koperasi yang anggotanya para konsumen akhir atau pemakai
${ }^{55}$ Ibid

${ }^{56}$ Ibid 
barang/jasa yang ditawarkan para pemasok di pasar.

Kedudukan anggota di dalam koperasi dapat berada dalam salah satu status atau keduanya. Dengan demikian pengelompokkan koperasi menurut status anggotanya berkaitan erat dengan pengelompokan koperasi menurut fungsinya. Jenis jenis koperasi didasarkan pada kesamaan kegiatan aktivitas dan kepentingan ekonomi anggotanya. Jenis koperasi terdiri atas 3 jenis yaitu, koperasi produksi (production cooperatives), koperasi konsumsi (consumer cooperatives), dan koperasi jasa (cooperative services). ${ }^{57}$

\section{1) Koperasi produksi}

Koperasi produksi

Pengertian koperasi produksi adalah jenis koperasi yang anggotanya terdiri atas para produsen dengan melakukan kegiatan usaha khusus penjualan barang barang produksi para anggotanya. Contoh, koperasi ternak, koperasi cengkeh, koperasi kopra, koperasi nelayan (Fishermen cooperative), dan koperasi kerajinan (arts cooperative).

\section{2) Koperasi konsumsi}

Koperasi konsumsi| Pengertian koperasi konsumsi adalah jenis koperasi yang memiliki anggota yang terdiri atas kumpulan konsumen, bergerak khusus dalam aktivitas penjualan barang barang konsumsi terutama barang kebutuhan para anggota koperasidan masyarakat sekitarnya. Contohnya koperasi karyawan (KOPKAR), koperasi pegawai republik Indonesia (KPRI), koperasi siswa/mahasiswa, koperasi RT, dan koperasi ABRI.

\section{3) Koperasi Jasa}

Koperasi jasa| Pengertian koperasi konsumsi adalah jenis koperasi yang melakukan kegiatan usaha dengan memberi pelayanan atau jasa kepada para anggota

57

http://www.apapengertianahli.com.Loc.cit khususnya dan masyarakat sekitarnya. contoh koperasi asuransi, koperasi simpan pinjam ataupun koperasi perkreditan.

Jenis jenis koperasi dapat juga dibagi atas jumlah jenis aktivitas usaha yang dimiliki. Koperasi tersebut adalah koperasi single purpose dan koperasi multipurpose. Pengertian koperasi single purpose adalah koperasi yang bergerak dalam satu bidang usaha seperti hanya bergerak dalam bidang jasa simpan pinjam, ada koperasi yang hanya bergerak dalam bidang konsumsi saja. Koperasi multi purpose adalah koperasi yang mengelola semua atau lebih dari satu bidang koperasi baik itu jasa, konsumsi maupun produksi. Koperasi jenis multi purpose terbilang koperasi yang sudah memiliki umur dan modal yang cukup besar untuk mengembangkan kapasitas, fungsi dan peranan anggota dalam koperasi. Contoh jenis koperasi multi purpose adalah KUD (Koperasi Unit Desa). Berdasarkan Undang-Undang Nomor 25 Tahun 1992 tentang koperasi, koperasi dapat dibedakan menurut keanggotaanya, yaitu koperasi primer dan koperasi sekunder. Koperasi primer adalah jenis koperasi yang beranggotakan orang seorang (berdasarkan ketentuan minimal 20 orang), sedangkan koperasi sekunder adalah jenis koperasi beranggotakan badan badan hukum koperasi (gabungan).

Berdasarkan fungsi dan peran koperasi, maka manfaat koperasi dapat dibagi menjadi dua bidang, yaitu manfaat koperasi dibidang ekonomi dan manfaat koperasi dibedang social. ${ }^{58}$

\section{a. Manfaat koperasi di bidang ekonomi, antara lain :}

a) Meningkatkan penghasilan anggota-anggotanya. Sisa Hasil Usaha (SHU) yang diperoleh koperasi dibagikan kembali kepada para anggotanya sesuai dengan jasa dan aktifitasnya.

b) Menawarkan barang dan jasa dengan harga yang lebih murah.

\footnotetext{
${ }^{58}$ Revrisond Baswir.Koperasi

Indonesia.BPFE-YOGYAKARTA.h.71.
} 
Barang dan jasa yang ditawarkan oleh koperasi lebih murah dari yang ditawarkan oleh toko-toko. Hal ini bertujuan agar barang dan jasa mampu dibeli para anggota koperasi yang kurang mampu.

c) Menumbuhkan motif berusaha yang berperikemanusiaan. Kegiatan koperasi tidak sematamata mencari keuntungan tetapi melayani dengan baik keperluan anggotanya.

d) Menumbuhkan sikap jujur dan keterbukaan dalam pengelolaan koperasi. Setiap anggota berhak menjadi pengurus koperasi dan berhak mengetahui laporan keuangan koperasi.

e) Melatih masyarakat untuk menggunakan pendapatannya secara lebih efektif dan membiasakan untuk hidup hemat.

\section{Manfaat koperasi dibidang social, antara lain :}

a) Mendorong terwujudnya kehidupan masyarakat damai dan tentram.

b) Mendorong terwujudnya aturan yang manusiawi yang dibangun tidak di atas hubungan-hubungan kebendaan tetapi diatas rasa ke

Menurut Undang-undang Nomor 25 tahun 1992 tentang Koperasi Pasal 4 dijelaskan bahwa :

a. Membangun dan mengembangkan potensi dan kemampuan ekonomi anggota dan masyarakat, berupaya mempertinggi kualitas kehidupan manusia, memperkokoh

perekonomian rakyat, mengembangkan

perekonomian nasional, serta mengembangkan kreativitas dan jiwa berorganisasi bagi pelajar bangsa

b. Berperan serta secara aktif dalam upaya mempertinggi kualitas kehidupan manusia dan masyarakat c. Memperkokoh

perekonomian rakyat sebagai dasar kekuatan dan ketahanan perekonomian nasional dengan koperasi sebagai sokogurunya

d. Berusaha untuk mewujudkan dan mengembangkan

perekonomian nasional yang merupakan usaha bersama berdasar atas asas kekeluargaan dan demokrasi ekonomi

Aspek Hukum Mengenai Pendirian Koperasi Undang-undang Nomor 25 Tahun 1992 tentang Perkoperasian. Koperasi adalah lembaga usaha yang dinilai cocok untuk memberdayakan rakyat kecil. Nilai-nilai koperasi juga mulia seperti keadilan, kebersamaan, kekeluargaan, dan kesejahteraan bersama dan merupakan salah satu badan usaha yang ikut membangun tatanan perekonomian nasional di Indonesia dalam rangka mewujudkan masyarakat adil dan makmur. $^{59}$

Brdasarkan Pasal 29 sampai dengan pasal 39 Undang-undang Nomor 25 Tahun 1992 tentang Perkoperasian menyebutkan bahwa :

Pasal 29 yakni :

1) Pengurus di pilih dari dan oleh anggota koperasi dalam rapat Anggota.

2) Pengurus merupakan pemegang kuasa rapat anggota.

3) Untuk pertama kali, susunan dan nam anggota pengurus dicantumkan dalam akta pendirian.

4) Masa jabatan pengurus paling lama 5 (lima) tahun.

5) Persyaratan untuk dapat dipilih dan diangkat menjadi 
anggota pengurus ditetapkan dalam anggaran dasar.

Pasal 30 yakni :

(1) Pengurus bertugas:

$$
\begin{aligned}
& \text { a. mengelola Koperasi dan } \\
& \text { usahanya; } \\
& \text { b. mengajukan rancangan } \\
& \text { rencana kerja serta } \\
& \text { rancangan rencana anggaran } \\
& \text { pendapatan dan belanja } \\
& \text { Koperasi }
\end{aligned}
$$

c. menyelenggarakan Rapat Anggota;

d. mengajukan laporan keuangan dan pertanggungjawaban pelaksanaan tugas;

e. menyelenggarakan pembukuan keuangan dan inventaris secara tertib;

f. memelihara daftar buku anggota dan pengurus.

(2) Pengurus berwenang:

a. mewakili Koperasi di dalam dan di luar pengadilan;

b. memutuskan penerimaan dan penolakan anggota baru serta pemberhrntian anggota sesuai ketentuan dalam anggaran Dasar;

c. melakukan tindakan dan dan upaya bagi kepentingan dan kemanfaatan koperasi sesuai dengan tanggung jawabnya dan keputusan rapat anggota.

Pasal 31 yakni :

\begin{tabular}{lrr} 
Pengurus & bertanggung jawab \\
mengenai & segala kegiatan \\
pengelolaan & Koperasi dan \\
usahanya & kepada rapat \\
Anggotaatau Rapat Anggota Luar & \\
biasa & \multicolumn{2}{l}{ Rapar }
\end{tabular}

Pasal 32 yakni:
1) Pengurus Koperasi dapat mengatakan pengelola yang diberi wewenang dan kuasa untuk mengelola usaha.

2) Dalam hal mengurus koperasi bermansud untuk mengangkat pengelola, maka pengakatan tersebut diajukan kepada rapat Anggota untuk mendapat persejutuan.

3) Pengelolaan bertanggung jawab kepada pengurus.

4) Pengelola usaha oleh pengelola tidak mengurangi tanggung jawab pengurus sebagai mana ditentukan dalam pasal 31 .

Pasal 33 yakni :

Hubungan kerja antara Pengelola dengan Pengurus Koperasi tunduk pada ketentuan hukum perikatan pada umumnya. Dengan demikian Pengelola bertanggung jawab sepenuhnya kepada Pengurus. Selanjutnya hubungan kerja tersebut sesuai dengan yang diperjanjikan dilakukan secara kontraktual.

Pasal 34 yakni :

1) Pengurus , baik bersamasam, maupun sendiri-sendiri, menanggung diderita koperasi, karena tindakan yang dilakukan dengan kesengajaan atau kelailanya.

2) Dismping penggantian kerugian tersebut, apabila tindakan itu dilakukan dengan kesengajaan, tidak menutup kemungkinan bagi penuntut umum untuk melakukan penuntutan.

Bagian Keempat (Pengawas)

Pasal 38 yakni :

Dalam hal Koperasi mengangkat Pengelola, Pengawas dapat diadakan secara tetap atau diadakan pada waktu diperlukan sesuai dengan keputusan Rapat Anggota. Hal ini tidak mengurangi arti Pengawas sebagai perangkat 
organisasi dan memberi kesempatan kepada Koperasi untuk memilih Pengawas secara tetap atau pada waktu diperlukan sesuai dengan keperluannya. Pengawas yang diadakan pada waktu diperlukan tersebut melakukan pengawasan sesuai dengan penugasan yang diberikan oleh Rapat Anggota.

Pasal 39 yakni :

(1) Pengawas bertugas:
a. melakukan pengawasan terhadap pelaksanaan kebijaksanaan dan pengelolaan koperasi;

b. membuat laporan tertulis tetng hasil pengawasanya

(2) Pengawas berwenang:

a. meneliti catatan yang ada pada koperasi;
b. mendapatkan segala keterangan yang diperlukan:
(3) Pengawas harus merahasiakan hasil pengawasannya terhadap pihak ketiga.

Pertanggungjawaban Pengurus dalam pengelolaan keuangan maupun manajemen koperasi, berdasarkan pada prinsip bahwa Pengurus memikul tugas bagaimana dapat menjalankan Koperasi dengan cara memperoleh dana yang tidak merugikan Koperasi, dan menggunakannya seefektif dan seefisien mungkin. Hal ini merupakan wujud dari tujuan manajemen keuangan Koperasi. Tujuan tersebut adalah memaksimisasi laba (SHU) yang pada akhirnya dapat memaksimisasi kesejahteraan an. ${ }^{60}$

A. Pertanggung Jawaban Pidana Bagi Pelaku Penggelapan dana Koperasi

UURI.No.25th.1992.perkoperasian.mediac enter.
Menurut Udang-Undang Nomor 25 Tahun 1992 Tentang perkoperasian

Permasalahan korupsi yang terjadi dikoperasi kebanyakan disebabkan oleh tindakan kepengurusan yang kurang professional, serta kurannya keterbukaan dan kerja sama antar anggota yang terdapat dalam koperasi. Untuk mengatasi permasalhan tersebut maka diperlukan penindakan yang tegas terhadap kepengurusan koperasi dengan cara mengadakan pengawasan secara berkalaterhadap pengurus dan anggota koperasi. Selain itu diperlukan juga kepengurusan yang professional. Kepungurusan professional adalah pengurus yang memiliki keahlian yang nyata serta jiwa yang aktif, kreatif, dan bertanggung jawab.

Meninjau dari permasalahan yang terjadi maka solusi yang tepat dalam menangani kasus ini yaitu :

1. Membentuk badan pengawas yang mengawasi segala aktifitas dan keuangan yang berkaitan dengan kegiatan kepengurusan dan anggota.

2. Menyeleksi setiap anggota dan pengurus yang akan bergabung dalam koperasi.

3. Memberikan pelatihan secara moral dan nyata tentang profesionalitas pengurus koperasi.

4. Memberi dan selalu menerapkan akan pentingnya kejujuran dan kedisiplinan dalam suatu koperasi.

Koperasi yang sehat juga harus melakukan rapat anggota tahunan (RAT) secara rutin. Hasilnya akan diaudit oleh akuntan publik. Undang-Undang Nomor 25 tahun 1992 tentang Perkoperasian baru itu akan memperbolehkan investor masuk menanamkan modalnya, lnvestor dapat menjadi sumber pembiayaan yang efektif bagi koperasi karena tidak mengenal dana hibah dan modal penyertaan. Seluruh kegiatan koperasi itu akan diawasi oleh Lembaga Pengawas Koperasi (LPK). Untuk diketahui, saat ini hanya 25 persen dari total 192 ribu koperasi di Indonesia yang aktif melakukan kegiatan pengukuhan Tim Satgas LPK-KSP untuk 10 provinsi diresmikan, akan menyusul pengukuhan tim sama ke provinsi lain 
sehingga akhirnya bisa mencapai seluruh provinsi Indonesia,

Seorang terdakwa jika akan dipidana harus ternyata bahwa tindakan yang dilakukan itu ternyata melawan hukum dan terdakwa mampu bertanggung jawab. Menurut Roeslan saleh, untuk adanya kesalahan yang mengakibatkan pidananya terdakwa (dipertangung jawabkan), maka terdakwa harus: ${ }^{61}$
a. Melakukan perbuatan pidana
b. Mampu bertanggung jawab
c. Dengan sengaja atau alpa
d. Tidak ada alasan pemaaf

Dalam tindak pidana pencucian yang dapat dipertanggungjawabkan ialah setiap orang yaitu orang perseorangan atau korporasi. Dalam tindakan pidana pencucian uang seseorang/koperasi telah dapat dipidana apabila telah terbukti melakukan perbuatan tindaka pidana pencucian uang yang sesuai dengan rumusan tindak pidana dalam UU TPPU, tanpa harus membuktikan unsur mampu bertanggungjawab dalam diri pelaku sebab dalam tindak pidana pencucian uang setiap orang dianggap mampu bertanggungjawab, dengan alasan bahwa tindak pidana pencucian uang sudah merupakan salah satu tindak pidana yang modern. Dimana para pelaku dalam tindak pidana tersebut adalah orang biasanya mempunyai intelektual tinggi, simpatik dan terpelajar. Pemikian juga mengenai kemampuan plaku untuk menyadari perbuatan berikut tindakannya tidak perlu lagi dipertanyakan. Apakah dia mampu menyadari atau tidak sebab sudah barang tentu pelaku pencucian uang menyadari hakekat tindakan yaitu untuk menyembunyikan/menyamarkan asal-usul kekayaan yang diperoelhnya dan tindak pidana dana berharap agar para penegak hukum atau masyarakat sulit untuk membuktikan dan melacak bahwa harta kekayaan tersebut berasal dari tindak pidana. Setiap orang yang melakukan

\footnotetext{
${ }^{61} \mathrm{http}: / /$ legal-

community.blogspot.com/2011/08/pertanggungjaw aban-pidana-pelaku-tindak.html
}

tindak pidana pencucian uang yang memenuhi unsur-unsur delik yang terdapat dalam UU tindak pidana pencucian uang dapat dikatakan mampu mempertanggungjawabkan perbuatannya yang tentu dapat diminta pertanggungjawaban atas perbuatannya tanpa perlu lagi dibuktikan. ${ }^{62}$

Berbagai kejahatan, baik yang dilakukan oleh orang perseorangan maupun oleh korporasi dalam batas wilayah suatu negara maupun yang dilakukan melintasi batas wilayah negara lain makin meningkat. Kejahatan tersebut antara lain berupa tindak pidana korupsi, penyuapan (bribery), penyelundupan barang, penyelundupan tenaga kerja, penyelundupan imigran, perbankan, perdagangan gelap narkotika dan psikotropika, perdagangan budak, wanita, dan anak, perdagangan senjata gelap, penculikan, terorisme, pencurian, penggelapan, penipuan, dan berbagai kejahatan kerah putih. Kejahatankejahatan tersebut telah melibatkan atau menghasilkan Harta Kekayaan yang sangat besar jumlahnya. Harta Kekayaan yang berasal dari berbagai kejahatan atau tindak pidana tersebut, pada umumnya tidak langsung dibelanjakan atau digunakan oleh para pelaku kejahatan karena apabila langsung digunakan akan mudah dilacak oleh penegak hukum mengenai sumber diperolehnya Harta Kekayaan tersebut. Biasanya para pelaku kejahatan terlebih dahulu mengupayakan agar Harta Kekayaan yang diperoleh dari kejahatan tersebut masuk ke dalam sistem keuangan (financial system), terutama ke dalam sistem perbankan (banking system). Dengan cara demikian, asal usul Harta Kekayaan tersebut diharapkan tidak dapat dilacak oleh para penegak hukum. Upaya untuk menyembunyikan atau menyamarkan asal usul Harta Kekayaan yang diperoleh dari tindak pidana dikenal sebagai pencucian uang (money laundering). 63

$$
{ }_{63}^{62} \text { Ibid }
$$

https://indonesaya.wordpress.com/tag/tanggung -jawab-korporasi-dalam-tindak-pidanapencucian-uang/ 
Bagi organisasi kejahatan, Harta Kekayaan sebagai hasil kejahatan ibarat darah dalam satu tubuh, dalam pengertian apabila aliran Harta Kekayaan melalui sistem perbankan internasional yang dilakukan diputuskan, maka organisasi kejahatan tersebut lama kelamaan akan menjadi lemah, berkurang aktivitasnya, bahkan menjadi mati. Oleh karena itu, Harta Kekayaan merupakan bagian yang sangat penting bagi suatu organisasi kejahatan. Untuk itu, terdapat suatu dorongan bagi organisasi kejahatan melakukan pencucian uang agar asal usul Harta Kekayaan yang sangat dibutuhkan tersebut sulit atau tidak dapat dilacak oleh penegak hukum. Perbuatan pencucian uang di samping sangat merugikan masyarakat, juga sangat merugikan negara karena dapat mempengaruhi atau merusak stabilitas perekonomian nasional atau keuangan negara dengan meningkatnya berbagai kejahatan. ${ }^{64}$

Berdasarkan penjelasan di atas, tindak pidana pencucian uang (money laundering) sebagai suatu kejahatan mempunyai ciri khas yaitu bahwa kejahatan ini bukan merupakan kejahatan tunggal tetapi kejahatan ganda. Hal ini ditandai dengan bentuk pencucian uang sebagai kejahatan yang bersifat follow up crime atau kejahatan lanjutan, sedangkan kejahatan utamanya atau kejahatan asalnya disebut sebagai predicate offense atau core crime atau ada negara yang merumuskannya sebagai unlawful actifity yaitu kejahatan asal yang menghasilkan uang yang kemudian dilakukan proses pencucian. Tindak pidana (crime) dapat diidentifikasi dengan timbulnya kerugian (harm), yang kemudian mengakibatkan lahirnya pertanggungjawaban pidana atau criminal liability. Yang pada gilirannya mengundang perdebatan adalah bagaimana pertanggungjawaban korporasi atau corporate liability mengingat bahwa di dalam Kitab Undang-undang Hukum Pidana (KUHP) Indonesia yang dianggap sebagai subyek hukum pidana hanyalah orang perseorangan dalam konotasi biologis yang alami (naturlijkee person). Di samping itu, KUHP juga masih menganut asas sociates delinquere non potest dimana badan hukum atau korporasi dianggap tidak dapat melakukan tindak pidana. Dengan demikian, pemikiran fiksi tentang sifat badan hukum (rechspersoonlijkheid) tidak berlaku dalam bidang hukum pidana. ${ }^{65}$

B. Landasan Pembatalan MK tentang Udang-Udang Nomor 17 tahun 2012

Undang-Undang Nomor 17 Tahun 2012, hari ini dibatalkan dengan Keputusan Mahkamah Konstitusi. Putusan Nomor 28/PUU-XI/2013 dalam amar putusannya antara lain memutuskan sebagai berikut $:^{66}$

1. Undang-Undang Nomor 17 Tahun 2012 Tentang Perkoperasian bertentangan dengan UndangUndang Dasar RI Tahun 1945.

2. Undang-Undang Nomor 17 Tahun 2012 Tentang Perkoperasian tidak mempunyai Kekuatan Hukum Mengikat.

3. Undang-Undang Nomor 25 Tahun 1992 Tentang Perkoperasian berlaku untuk sementara waktu sampai dengan terbentuknya UndangUndang yang baru.

4. Putusan tersebut dibacakan pada tanggal 28 mei 2014 pukul 09.30 WIB oleh Hakim Ketua : HAMDAN ZOELVA.

(Sumber : Publikasi/Humas Ikatan Notaris Indonesia).

UU No. 25 berlaku kembali dan itu berarti seluruh modal yang sudah dikonversi dikembalikan lagi ke Simpanan Pokok dan Simpana Wajib Anggota. Agak ribet buat kita Notaris, karena kita masih bingung treat untuk mengembalikan Koperasi yang sudah terbentuk dengan UU No. 17 tersebut. $^{67}$

$$
{ }^{65} \text { Ibid }
$$

https://adityapatria.wordpress.com/2014/05/28/pem batalan-undang-undang-nomor-17-tahun-2012tentang-perkoperasian/

$$
{ }^{67} \text { Ibid }
$$

$$
{ }^{64} \text { Ibid }
$$


Salah satu alasan utama kemungkinan digugatnya UU No. 17 di MK adalah bahwa pengertian Koperasi sebagai kumpulan orang-orang digantikan dengan kumpulan Modal yang ngga lain adalah Konsep dari Perseroan Terbatas. Mungkin tadinya niat ini ingin menguatkan Koperasi dari segi permodalan agar dengan Sertifikat Modal Koperasi (SMK) atau Saham Koperasi, anggota tidak selalu serta merta menyatakan keluar dan mengambil Simpanan Pokok dan Simpanan Wajibnya selama ini sehingga jika dilakukan secara masif akan membuat Koperasi collapse.

Akan tetapi, kita juga harus siap dengan konsekuensi awal, yaitu di mana Unit Simpan Pinjam di dalam Koperasi Serba Usaha dapat dikuras habis oleh Unit Usaha lain yang haus akan permodalan. Dan berdasarkan UU No. 25 tidak ada LPS bagi Unit atau Koperasi Simpan Pinjam, sehingga Koperasi harus bisa menjamin kelangsungan simpanan Anggota di dalam usaha SImpan Pinjam ini.
2. Pertanggung Jawaban Pidana Bagi Pelaku Penggelapan dana Koperasi Menurut Udang-Undang Nomor 25 Tahun 1992 Tentang perkoperasian Keberadaan lembaga penjamin simpanan koperasi itu bertujuan memberi perlindungan bagi nasabah koperasi. Dan Undang-Undang Nomor 25 tahun 1992 tentang Perkoperasian baru itu akan memperbolehkan investor masuk menanamkan modalnya, lnvestor dapat menjadi sumber pembiayaan yang efektif bagi koperasi karena tidak mengenal dana hibah dan modal penyertaan. Seluruh kegiatan koperasi itu akan diawasi oleh Lembaga Pengawas Koperasi (LPK). Untuk diketahui, saat ini hanya 25 persen dari total 192 ribu koperasi di Indonesia yang aktif melakukan kegiatan pengukuhan Tim Satgas LPK-KSP untuk 10 provinsi diresmikan, akan menyusul pengukuhan tim sama ke provinsi lain sehingga akhirnya bisa mencapai seluruh provinsi Indonesia,

\section{DAFTAR PUSTAKA}

\section{KESIMPULAN}

Berdasarkan pemaparan yang telah disampaikan maka penelitian ini memberikan pokok-pokok kesimpulan sebagai berikut:

1. Pertanggungjawaban Pengurus dalam pengelolaan keuangan maupun manajemen koperasi, berdasarkan pada prinsip bahwa Pengurus memikul tugas bagaimana dapat menjalankan Koperasi dengan cara memperoleh dana yang tidak merugikan Koperasi, dan menggunakannya seefektif dan seefisien mungkin. Hal ini merupakan wujud dari tujuan manajemen keuangan Koperasi. Tujuan tersebut adalah memaksimisasi laba (SHU) yang pada akhirnya dapat memaksimisasi kesejahteraan.

\section{LITERATUR}

Jhony ibrahim, Teori \& Metode Penelitian Hukum Normatif, Banyumedia Publishing, Malang, Tahun 2006.

Peter Mahmud Marzuki, Penelitian Hukum, Kencana Prenadia Group, Jakarta, Tahun 2010

Revrisond Baswir, Koperasi indonesia, BPFE-YOGYAKARTA, Yogyakarta, Tahun 1997/2000

Dra.Ninik Widiyanti, Menejemen Koperasi, Rineka Cipta, Jakarta, Tahun 2007

PERATURAN

PERUNDANG-

Undang-undang Dasar Negara Republik Indonesia Tahun 1945

Kitab Undang-undang Hukum Pidana (KUHP) 
Undang-undang Nomor 25 Tahun 1992

Tentang Perkoperasian

\section{INTERNET :}

http://repository.fhunla.ac.id/?q=node/136

http://rechtsvinding.bphn.go.id/jurnal_onl ine/Penanganan $\% 20$ Kekerasan $\% 2$ 0Terhadap\%20Anak.pdf

https://adityapatria.wordpress.com/2014/05 /28/pembatalan-undang-undangnomor-17-tahun-2012-tentangperkoperasian/ 